\title{
TITLE:
}

\section{ANALYTICAL STUDIES ON MARINE LAMP-COMMUNITIES}

AUTHOR(S):

Maeda, Hiroshi

\section{CITATION:}

Maeda, Hiroshi. ANALYTICAL STUDIES ON MARINE LAMP-

COMMUNITIES. PUBLICATIONS OF THE SETO MARINE BIOLOGICAL LABORATORY 1951, 1(4): 195-213

ISSUE DATE:

1951-05-31

URL:

http://hdl.handle.net/2433/174444

RIGHT: 


\title{
ANALYTICAL STUDIES ON MARINE LAMP-COMMUNITIES*
}

\author{
HiROSHI MAÉDA \\ Biological Institute, Kobe University \\ With 7 Text-figures and 4 Tables
}

\section{Introduction}

From remote times, Japanese have used light for fishing at night. The torch was the only source of light till the middle of the Meiji era, when the petroleum lamp took its place, then appeared the Acethylen lamp and lastly the electric lamp connected to the battery or the dynamo. These lamps are now called "the fish gathering lamps", and they are indispensable in various districts for fishing sardines, scombers, Carangid fishes etc.

The scientific investigations have been made since 1926 on many such problems as the economic relations and the technique of the lamp fishery, the physical relations between the light and the water, or the reactions of some fishes to light. There is, however, no synecological investigation on the fish community formed under the lamp. It is obvious that the formation and the maintenance of the community under the lamp is controlled not only by phototaxis, but also by complicated coactions among the gathered fishes, of which the food relation seems to be the most significant factor.

In order to learn the food relations and their significance in determining the situation of each component fish in the community under the lamp, I planned a series of observations under the direction of Prof. D. MiYadi and Dr. T. TokiokA. I was helped much during the work by many fishermen with their vigorous labour as well as their useful suggestions. To all these gentlemen I express here my hearty thanks. I must also record my thanks for the financial aid given by the Hattori-Hôkôkai.

\section{Methods}

The observations were made during the period from August to November of 1950 , on board of small fishing boats professionally working near the Seto

* Contributions from the Seto Marine Biological Laboratory, No. 161.

Publ. Seto Mar. Biol. Lab., I (4) 1951. 


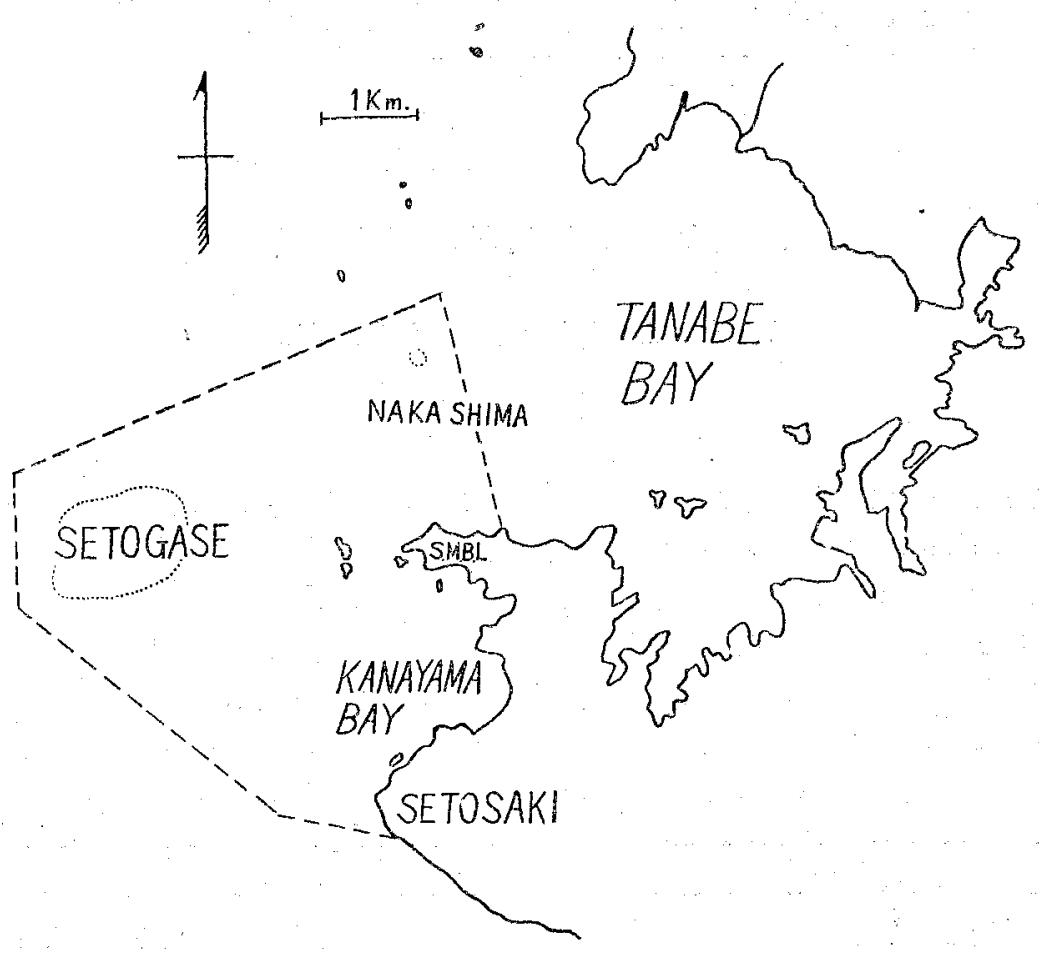

Fig. 1. Sketch map of the observation field. S.M.B.L.-Seto Marine Biological Laboratory.

Marine Biological Laboratory (Fig. 1), which is situated on the west coast of the Kii Peninsula. The sea around the Laboratory is strongly influenced by a branch of the warm "Kuroshio" current. The depth of the sea reaches 10$20 \mathrm{~m}$.

The light sources were $30-100$ C.P. electric lamps, which were used either being immersed in the water or above it.

The food samples, i.e. stomach contents, were collected from the catches hauled during my observations.

\section{Lamp Animals and Lamp Communities}

I propose to use the terms "lamp animals" and "lamp community" in the same sense as "torch plankton", i.e. the animals and their assemblage under the lamp. Among lamp animals, the pelagic fishes of the surface layer are the most important members, next come the middle layer fishes like Parapristipoma trilineatum (THunBerG) and Pempheris macrolepidotus (BLOCH \& SCHNEIDER), and lastly the benthonic fishes, which play insignificant rôle among 
the lamp community although quite rich in the number of species. The presence of the benthonic fishes under the lamp is verifiable only by angling.

The lamp animals observed during my study were:-

(1) Plankton

Polychaeta

Copepoda

Calanus spp.

Oncaea venusta

Stomatopoda

Larvae

Amphipoda

Ostracoda

Pyrocypris sp.

Cypridina hilgendorfii

Gammarid amphipods*

Hyperiid amphipods

Isopoda

Macrura

Cumacea

Puerulus

Natantians

Mysidacea

Siriella watasei*

Tenagomysis orientalis

Brachytra

Megalopae*

(2) Mollusca.

Ommastrephes sloani pacificus STEENSTRUP

Doryteuthis kensaki (WAKIYA \& ISHIKAWA)

Octopus variabilis SASAKI

(3) Pisces

About $45 \%$ of the food fishes inhabiting in the vicinity of Seto are said to gather under the lamp.

a) Regular members (gathered under the lamp at the frequency more than $60 \%$ of my observations).

Elrumeus micropus (T. \& S.)

Amblygaster melanostricta (T. \& S.) Tylosurus anastomella (C. \& V.)

Engraulis japonica T. \& S.

Decapterus muroadsi (T. \& S.)

Stolephorus japonicus (HoutTUYN)

Trachurus trachurus (LINNE)

Harengula zunasi BLEEKER

Cypselurus agoo (T. \& S.)

Trachurops crumenophthalmus (BLOCH)

Sphyraena japonica C. \& V.

Pempheris macrolepidotus

Atherina bleekeri GüNTHER

(Bīoch \& Schneider)

Parapristipoma trilineatum

(Thunberg)

b) Frequent visitors (gathered at the frequency of $45-60 \%$ ).

* shows the quantitatively important animal. 
Sco'iodon walbeehmi (BLEEKER)

Dorosoma thrissa (LINNÉ)

Hemirhamphus sajori (T. \& S.)

Gymnothorax kidako (T. \& S.)

Scomber scombrus japonicus (HoUTTUYN) Scolopsis nagasakiensis (TANAKA)

Scomber scombrus tapeinocephalus

(BLEEKER)

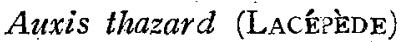

Auxis tapeinosoma (BLEEKER)

Euthynnus yaito KISHINOUYE

Trichiurus haumeal (FORSKÅ).

Caranx mertensi $\mathrm{C}$. \& V.

Apogon semilineatus 'T. \& $\mathrm{S}$.
Epinephelus moara moara (T. \& S.)

Scombrops boops (HoutTUYN)

Priacanthus hamrur (FORSKÅ)

Lutianus vitta (QUOY \& GAIMARD)

Gymnocranius griseus (T. \& S.)

Lethrinus haematopterus T. \& $\mathrm{S}$.

Pagrosomus major (T. \& S.)

Teuthis fuscescens (HoutTuYN)

Sphoeroides spadiceus (RICHARDSON)

Sphoeroides vermicularis (T. \& S.)

Sphoeriodes inermis (T. \& S.)

c) Occasional visitors (gathered at the frequency less than 45\%. This column is composed of members which were observed by myself and those recommended by Mr. T. KANAYA, a skillful fisherman in the vicinity).

Isurus glaucus (MüLleR \& HenLe) Coryphaena hippurus LINNÉ

Holocentrus ruber (FORSKÄL) Lutianus fulviflamima (FORSKÅL)

Sarda chilensis (C. \& V.) Therapon oxyrhynchus T. \& S.

Caranx sexfasciatus Quoy \& GAIMARD Girella punctata GRAY

Kyphosus cinerascens (ForSKÄL) Sebastiscus marmoralus (C. \& V.)

Ostracion diaphanum Areliscus joyneri (GüNTHER)

Bloch \& SchneIDER Areliscus purpureomaculalus (REGAN)

Ostracion tuberculatum LINNÉ

4) Mammalia

A certain species of dolphin, probably Dolphinus.

\section{Food Ranks of Main Lamp Fishes}

The stomiach contents of the main lamp fishes collected during my observations are shown in Table 1. From this table and referring to my actual observations on the boat as well as the suggestions given by Messrs. K. OE and S. WADA, the lamp animals may be classified into the following eight groups.

1) Prey Group.

This group represents the lowest class in the food chain in this temporal community formed artificially. There is no producer or smaller prey nourishing group. This group consists of planktonic animals and Engraulis of "Shirasu" stage which are eaten chiefly by secondary predators, although a part of them 
Table 1. Stomach contents of main lamp fishes.

\begin{tabular}{|c|c|c|c|c|c|c|c|c|c|}
\hline $\begin{array}{l}\text { Stomach } \\
\text { contents } \\
\text { Fishes }\end{array}$ & $\frac{\sqrt{2}}{\frac{2}{3}}$ & 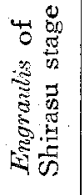 & 离 & 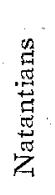 & $\frac{\mathscr{0}}{g}$ & 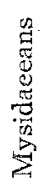 & $\begin{array}{l}\frac{0}{8} \\
0 \\
0 \\
0 \\
0 \\
0 \\
0\end{array}$ & 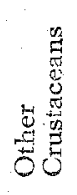 & 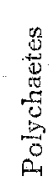 \\
\hline Stolephorus & & & & & & & $\begin{array}{l}\mathrm{R} \\
\mathrm{M}\end{array}$ & & \\
\hline Engraulis & & $\stackrel{C}{\Lambda}$ & $\stackrel{+}{\mathrm{M}}$ & & $\begin{array}{l}\mathrm{R} \\
\mathrm{S}\end{array}$ & $\begin{array}{l}R \\
S\end{array}$ & $\begin{array}{l}\mathrm{H} \\
\mathrm{S}\end{array}$ & $\begin{array}{l}\mathrm{R} \\
\mathrm{S}\end{array}$ & \\
\hline Pempheris & & $\begin{array}{l}R \\
A\end{array}$ & $\mathrm{C}$ & $\begin{array}{l}+ \\
S\end{array}$ & $\begin{array}{l}C \\
A\end{array}$ & $\begin{array}{l}\mathrm{C} \\
\mathrm{A}\end{array}$ & & $\begin{array}{l}t \\
S\end{array}$ & $\begin{array}{l}\mathrm{T} \\
\mathrm{S}\end{array}$ \\
\hline Carangidae & $\begin{array}{l}R \\
S\end{array}$ & $\mathrm{O}$ & $\begin{array}{l}+ \\
\mathrm{M}\end{array}$ & $\begin{array}{l}\mathrm{R} \\
\mathrm{S}\end{array}$ & $\begin{array}{c}C \\
4\end{array}$ & $\begin{array}{l}\mathrm{h}^{2} \\
\mathrm{~S}\end{array}$ & & $\begin{array}{l}R \\
S\end{array}$ & $\begin{array}{l}\mathrm{P} \\
\mathrm{S}\end{array}$ \\
\hline Sphyraena & C & $\begin{array}{l}\mathrm{R} \\
\mathrm{A}\end{array}$ & 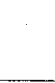 & & & & & & \\
\hline Trichiurus & $\stackrel{C}{\Lambda}$ & $\begin{array}{l}R \\
S\end{array}$ & $\begin{array}{l}\mathrm{R} \\
\mathrm{S}\end{array}$ & $\begin{array}{l}\pi \\
\mathrm{s}\end{array}$ & & & & $\begin{array}{l}R \\
S\end{array}$ & \\
\hline Atherina & & $\begin{array}{l}B \\
S\end{array}$ & & & * & + & $\frac{\mathrm{R}}{\mathrm{M}}$ & $\begin{array}{l}\mathrm{R} \\
\mathrm{S}\end{array}$ & \\
\hline $\begin{array}{l}\text { Oypselurus } \\
.\end{array}$ & & & & & & & & & \\
\hline Teuthis & & & & · & & & & & \\
\hline Tetraodontidae & $\begin{array}{l}\mathrm{R} \\
\mathrm{S}\end{array}$ & & & $\begin{array}{l}\mathrm{R} \\
\mathrm{S}\end{array}$ & & & & & \\
\hline Euthynnus & & & & & & & & & \\
\hline
\end{tabular}

Frequency

$$
\begin{aligned}
& \mathrm{C}: \text { common } \\
& +\mathrm{t} \text { medium } \\
& \mathrm{R}: \text { rare }
\end{aligned}
$$

Quantity

$$
\begin{aligned}
& \text { A: abundant } \\
& \mathrm{M}: \text { medium } \\
& \mathrm{S}: \text { scarse }
\end{aligned}
$$

serves as the food of primary predators.

\section{2) Primary Predators.}

Fishermen classify the lamp fishes into two groups, one consisting of prey fishes and the other comprising predators. The former is commonly called "Komono" (ko=small, mono=things) : e.g. Clupeid fishes and Pempheris.

The primary predators, proposed here, consist chiefly of "komono", namely Stolephorus, Engraulis and Pempheris, of which the last one has the characteristics between the primary and secondary predators. 
3) Secondary Predators.

This group and the primary predators are the main objects of lampfishery using a net. The members of this group feed chiefly on the prey group and occasionally on the primary predators.

This group consists of medium- or large-sized plankton-feeders, e.g. Carangids and Scombrids.

4) Tertiary Predators.

Fishermen call the predators belonging to classes higher than the tertiary as a whole, "Oi-mono" (oi means to disperse), and hate their visit to the lamp very much, because by those fishes are dispersed the secondary and primary predators which are the chief objects of the fishery. Fishes belonging to the tertiary predators feed mainly on the primary predators and occasionally on the secondary predators, but scarcely on the prey group.

Sphyraena and molluscan Decapods are the important members of this class. The former is, however, eaten by the latter, consequentiy the latter may be said to occupy the higher situation than the former.

5) Quarternary Predators.

This group feeds mainly on the primary, secondary, and the tertiary predators. The dispersing influence of fishes in this class is not so strong as that of the end predators, although it is much stronger than that of the tertiary predators.

6) E.xd Predators (Community destroyers.)

This group occupies the highest position in the food-pyramid and may be called the destroyers of the community formed under the lamp, since the fishes vanish completely at the appearance of the members of this group. Squalus, Coryphaena and Dolphinus are members of this group in the upper layer of the water; the latter two are much rarer than the first. Epinephelus is a benthonic member of this group; its destroying activity is not strong.

7) Benthonic Group.

The food relations and consequently the food order of the benthonic fishes are not made clear.

8). Indifferent Fishes.

In this" category are included many fishes which assemble under the lamp, but each has no significant relation to other fishes on account of the fewness, the short staying time or the fact that it seldom eats under the lamp. Some of these fishes state between the lamp fishes and those not gathered by the light. Following is the list of members of this group classified according to their habits in the day time.

a) Prey Group. 
Benthonic crustaceans and jelly fishes.

b) Primary Predators.

Atherina, Cypselurus, and Mugil.

c) Secondary Predators.

Ophichthus and Euthymus.

d) Tertiary Predators.

Tylosurus.

e) Benthonic Groups.

Teuthis and Ostracion.

\section{Situation of a Fish in the Same Food Rank}

The situation of a member fish in a certain food rank may be determined on following standards, which were derived chiefly from food relations.

1. The size of a lower rank is, in general, smaller than that of the higher rank. The fish of the young stage belongs to the lower rank than that of its full-grown stage.

2. The situation of a predator within the same food rank is roughly proportional to the order of the prey fish eaten by it.

3. The fish of lower food rank usually occupies the nearer position to the light source among the lamp community.

4. The fish of lower food rank is controlled more strongly by the light.

5. The fish with stronger dispersing infuence on the community is placed in higher rank.

The smaller planktonic crustaceans serve as food merely for the primary predators. The larger planktonic crustaceans and Engranlis of the Shirasu stage are eaten by predators of 1 st to 4 th ranks. But the behavior of the latter resembles rather to primary predators than to that of prey groups.

Stolephorus and Engraulis form a single common shoal when they are not sufficiently numerous to form separate shoals. There is no direct food relation between Slolephorus and Engraulis. The former feeds absolutely on smaller planktonic crustaceans, especially Oncasa venusia, while the latter on larger planktonic crustaceans and Shirasu. Consequently, Engraulis may be placed in the higher position in a food chain than Stolephorus.

The plankton feeders under the lamp usually form a compact group, which swims around the light at a constant distance from it. They take the food actively under the lamp. Atherina and Cypselurus differ considerably in their behaviors under the lamp. They dash to the light and then swim away from there. They take little food under the lamp. These peculiarities are much more conspicuous in Cypselums than in Aherina Musil also shows such a 
peculiarity as Cypselurus but more conspicuously. From these observations, it may safely be said that in the primary predator, the lamp fishes do not form a discontinuous group, but are connected with those not assembling to the light through the intermediate forms such as Atherina-Cypselurus-Mugil.

Although Pempheris and Carangid fishes form a common shoal when they are few, they form distinctly separated groups when they are numerous. They resemble with each other very closely in the behavior under the lamp. Once I tested the behavior of some lamp fishes enclosed in a net by changing the distance of light from the net, when Engraulis exhibited a strong photopositive movement, while Pempheris and Carangids were quite indifferent. Carangid fishes belong to the secondary predators and feed on planktonic crustaceans as well as Shirasu and small-sized Clupeid fishes. Pempheris, on the contrary never eats the Clupeid fishes, although it takes the food much more than the common primary predators. From these reasons, I prefer to treat Pempheris as a primary predator placing it at the highest position in that rank.

Carangid fishes form very stable groups under the lamp, if there is a few prey. Scombrid fishes need much "preys to keep their group near the lamp. Fishermen use "maki-e" in this purpose; here "maki" means "to throw" and "e" indicates the food. Euthynnus is very unstable under the lamp, it swims away from a lamp to another very frequently, and even the "maki-e" of Shirasu can not retain them under a same lamp. It seldom takes preys under the lamp as in Cypselurus and Mugil. Thus, the secondary predators in the lamp fishes are continuous to the fishes not assembling to the light through the route-Carangids-Scombrids-Euthynums-, as in the case of the primary predators.

Sphyraena and molluscan Decapods must be the tertiary predators, because they eat Carangid fishes. Notwithstanding the fact that Sphyraena eats Carangids, the latter does not avoid the former. Decapods feed on Carangids and Sphyraena under the lamp. In this case, Carangids disperse and avoid Decapods, while Sphyraena does not avoid the squids. Thus, these three fishes may de arranged in the following orders:-Carangids-Sphyraena-molluscan Decapods.

The appearance of Trichiurus, Epinephelus, Squalus; Coryphaena and Dolphinus causes the complete dispersion of the fish group formed under the lamp. They are very few in number and visit the lamp only rarely. It seldom occurs that two or more species of them appear at the same time. Therefore, the food relation between them is quite obscure. The commonest one is Trichiurus, which is sometimes eaten by Epinephelus. Epinephelus, on the other hand, is 


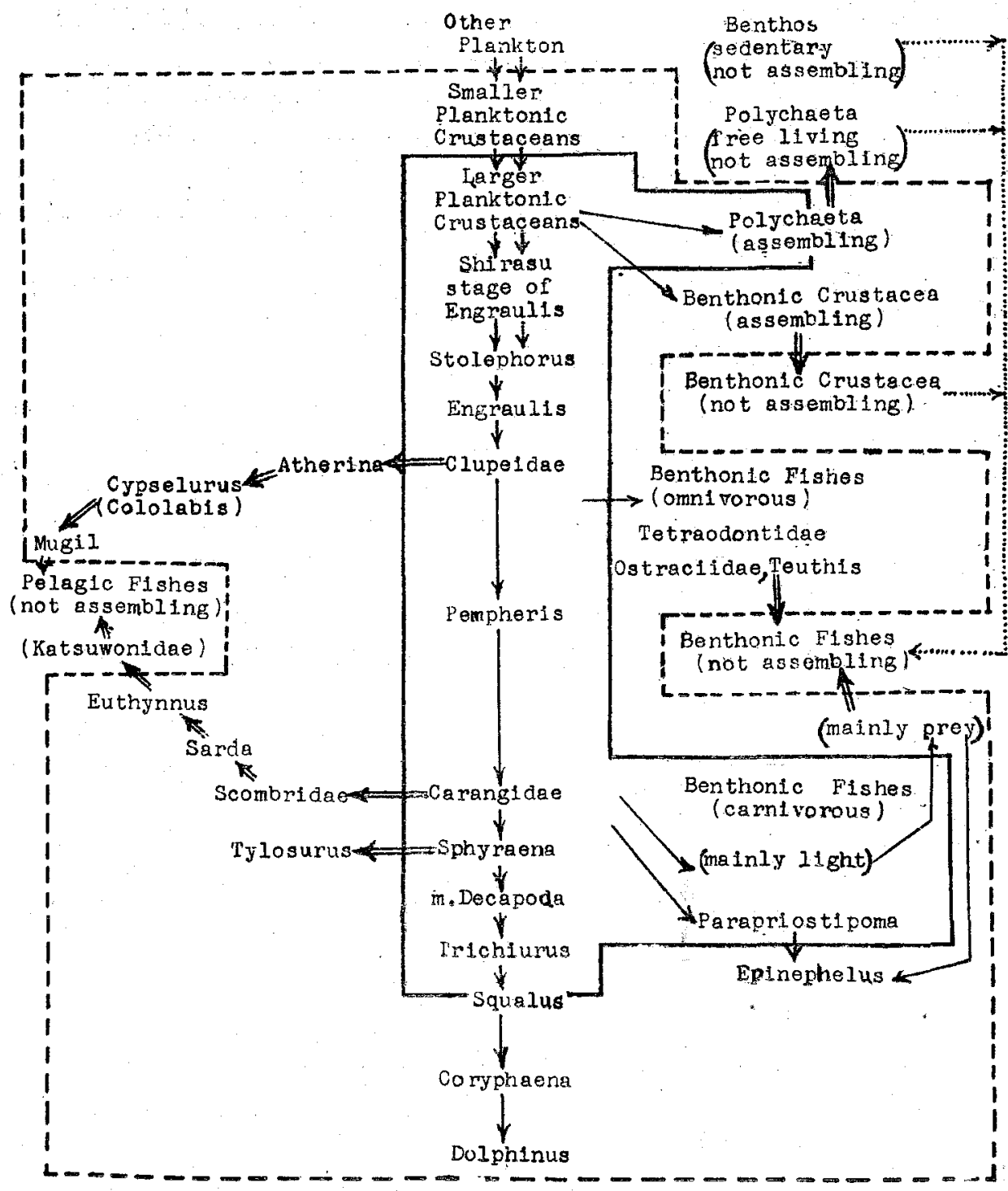

Fig. 2. Coaction in the lamp-community.

$\rightarrow$ shows the direction of the ascension of food order.

$\Rightarrow$ shows the direction of the decrease of the light-assembling tendency in members of the same rank.

$\rightarrow$ shows the direction of the increase of the capacity to assemble to the light, i. $\epsilon$. owing chiefly to the increase of the locomotive power.

Animals enclosed within the full line are the regular members of lamp-community having close interrelations with one another.

Animals enclosed between the broken line and the full one are those assemb'ing under the lamp, but their behavior to light is rather unstable and interrelations between them not so strong as in the predating animals. 
bitten by Squalus on the way being angled up. Usually Epinephelus and Squalus occupy vertically separated habitat, and there is no food relation between them, although Epinephelus resting among rocks is said to escape Squalus by the appearance in its neighborhood. From these facts as well as the degree of the dispersing activity and the tendency to approach the light, these animals seem to be arranged in the following order:-Trichiurus-Epinephelus-Squalus-Coryphaena-Dorphinus.

The whole relations mentioned above may be summarized as in Fig. 2.

\section{Quantity of Lamp Fishes in Each Food Rank}

It is very hard to know the real amount of fishes assembling under the light. There is, indeed, no clear boundary, in which the animals may be said being assembled to the light; or practically it is impossible to estimate or catch the whole animals in the sphere, if such a boundary is admitted. In the following two tables, I tried to give some hints on item of this chapter.

Table 2. The biomass in each haul by present net indicated in weight (Kg.)

\begin{tabular}{|l|c|c|c|c|c|c|c|}
\hline \multicolumn{1}{|c|}{ haul number } & 1 & 2 & 3 & 4 & 5 & 6 & Total \\
\hline food class & 14 & 15 & 11 & 6 & 17 & 15 & 78 \\
\hline Primary predators & 4 & 7 & 4 & 3 & 0.5 & 1 & 19.5 \\
\hline Secondary predators & 5 & 1 & 1 & 1 & 0 & 0.5 & 8.5 \\
\hline Tertiary predators & 0 & 0 & 0 & 0 & 0 & 0 & 0 \\
\hline $\begin{array}{c}\text { Quarternary predators } \\
\text { Total }\end{array}$ & 23 & 23 & 16 & 10 & 17.5 & 16.5 & 106.0 \\
\hline
\end{tabular}

Tab'e 3. Frequency of appearance of the animals in each food rank in 24 cases.

\begin{tabular}{|c|c|c|c|c|}
\hline $\begin{array}{c}\text { Prey } \\
\text { group }\end{array}$ & $\begin{array}{c}\text { Primary } \\
\text { predators }\end{array}$ & $\begin{array}{c}\text { Secondary } \\
\text { predators }\end{array}$ & $\begin{array}{c}\text { Tertiary } \\
\text { predators }\end{array}$ & $\begin{array}{c}\text { Quarternary } \\
\text { predators }\end{array}$ \\
\hline 24 & 23 & 21 & $20(11)^{*}$ & 4 \\
\hline
\end{tabular}

* Here included many cases of the appearance of small molluscan Decapods which served as the primary ptedators rather than the teriary ones. Thus only 11 cases were cons.dered to be the real one.

The primary and the secondary predators are usually found as groups, but the tertiary and quarternary predators are occasional visitors to the light and the end predators are seldom observable. I could not find actually any animal of the end predators during the period of my observation. 
The amount of the primary predators is the largest of all. Among them, Engraulis is most abundant, next comes Stolephorus and then followed by Pempheris. The amount of the secondary predators falls roughly between $1 / 10$ and $1 / 4-1 / 2$ of that of the primary predators, although the former may surpass the latter when Euthynnus or Scombrids gather in quantities. The amount of the tertiary predators is no more than a small part of the secondary predators, and the quarternary predators about a half of the tertiary predators. The members of the prey group occupy a small central space of the shoal under the lamp; moreover, they are very small in size. Consequently, the amount of this group is considered to be much smaller than that of the primary predators.

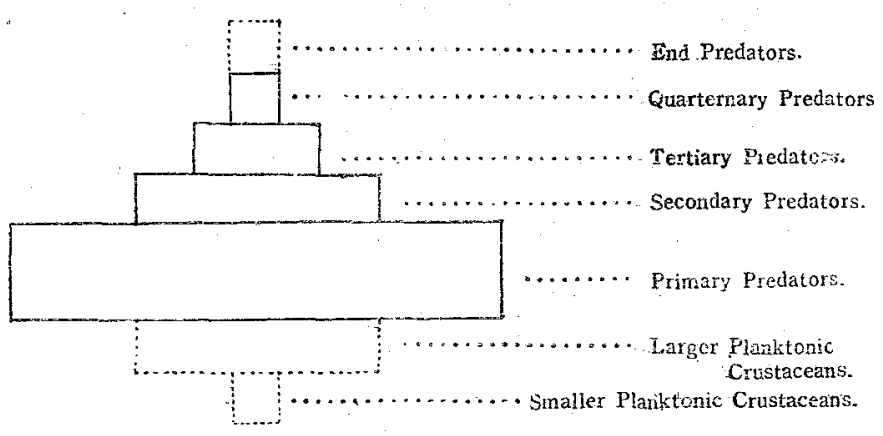

Fig. 3. Quantity of the lamp fishes in each food rank.

Fig. 3 represents the summarized idea of the above descriptions. From this figure, it may be said that the lower components in the present ecosystem, formed temporarily under the lamp, do not build the wide basal portion of the food pyramid as in the ordinary ecosystem.

So it may be supposed that the amounts of the prey group, the primary and the secondary predators are not only controlled by their preys but also the other factors induced by light:

\section{Social Structure of the Lamp-Community}

We can actually observe merely the structure of the fish community in the superficial layer of the water. That of the deeper strata is only presumable from the results of angling or netting.

The structure of lamp community seems to be affected by both the color and intensity of light, current and predating action of the fish. Even one of these factors may affect the community so strongly that it may become very small and unstable, and consequently under certain cases when the two factors 
are effective together practically no animal group is formed under the lamp.

(1) Standard form.

The structure of the community under the condition when neither current nor predating action are effective may be called the standard form.

When the lamp is lighted, many fishes assemble irregularly one after the other and after a short time they attain an equilibrium condition in the

Fig. 4. Four actual cases of the standard form.

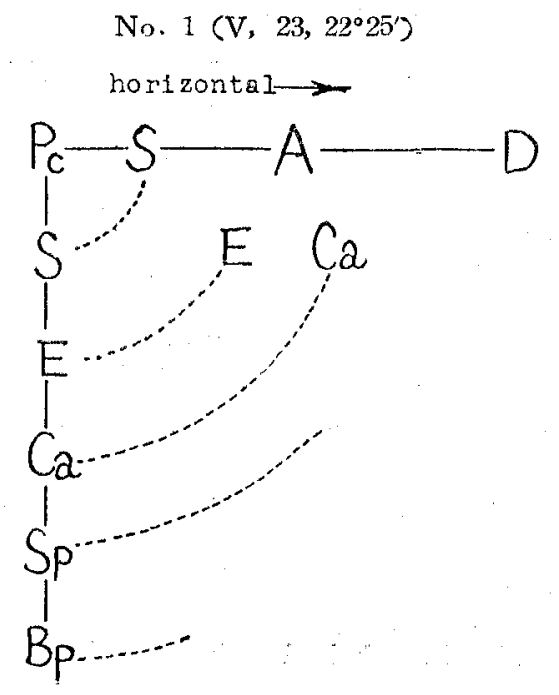

No. 4 (VIII, $6,2^{\circ} 40^{\circ}$ )

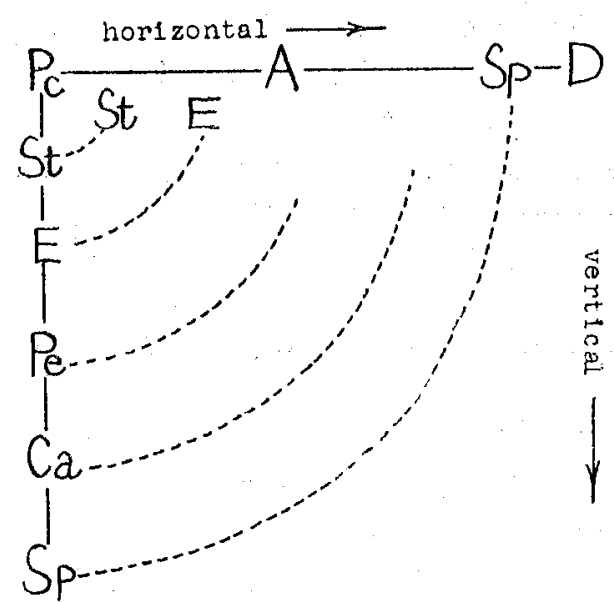

No. 3 (VIII, 6, $1^{\circ} 00^{\prime}$ )

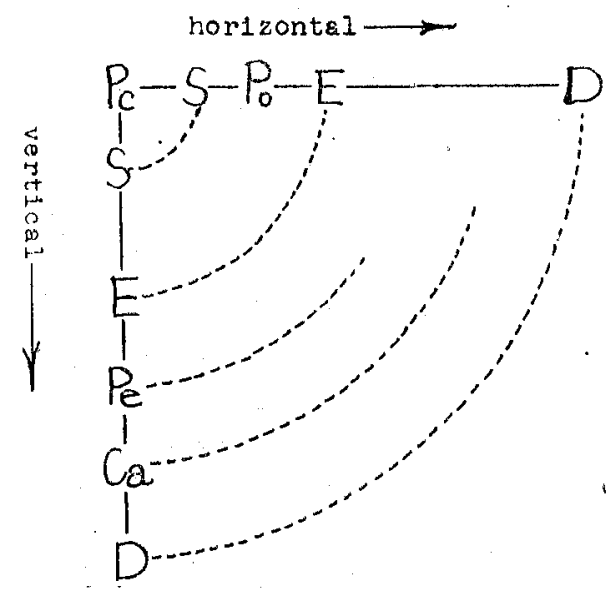

No. 8 (VIII, $11,19^{\circ} 45^{\prime}$ )

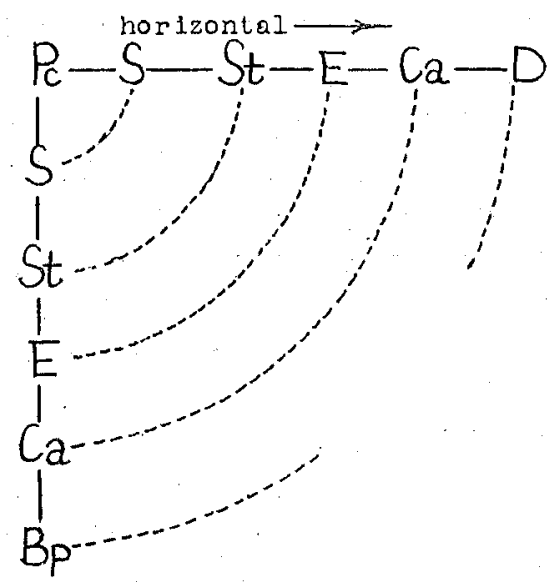

Pc: Planktonic Crustaceans, S: Shirasu stage of Engraulis, Pu: Polychretes,

St: Stolephorus, E: Engraulis, Pe: Pempheris, Ca: Carangidae,

Sp: Sphyraena, D: molluscan Decapods, Bp: Benthonic Fishes, A: Atherina. 
standard form. Fig. 4 is a schematic representation of the standard form in my observation. It is learned from these schemata that the nearest part to the lamp is occupied by the prey group, the next zone by the primary predators and then the more peripheral in the situation the higher in the food order. The vertical structure is supposed to be the same as the horizontal structure rotated at right angle. Here, the fishes of the "indifferent group" are seen only in the superficial layer, and the benthonic fishes only in the deeper layer. All other structures may be interpreted as modified forms of this standard form.

Fig. 5. Pictorial representation of the standard form.

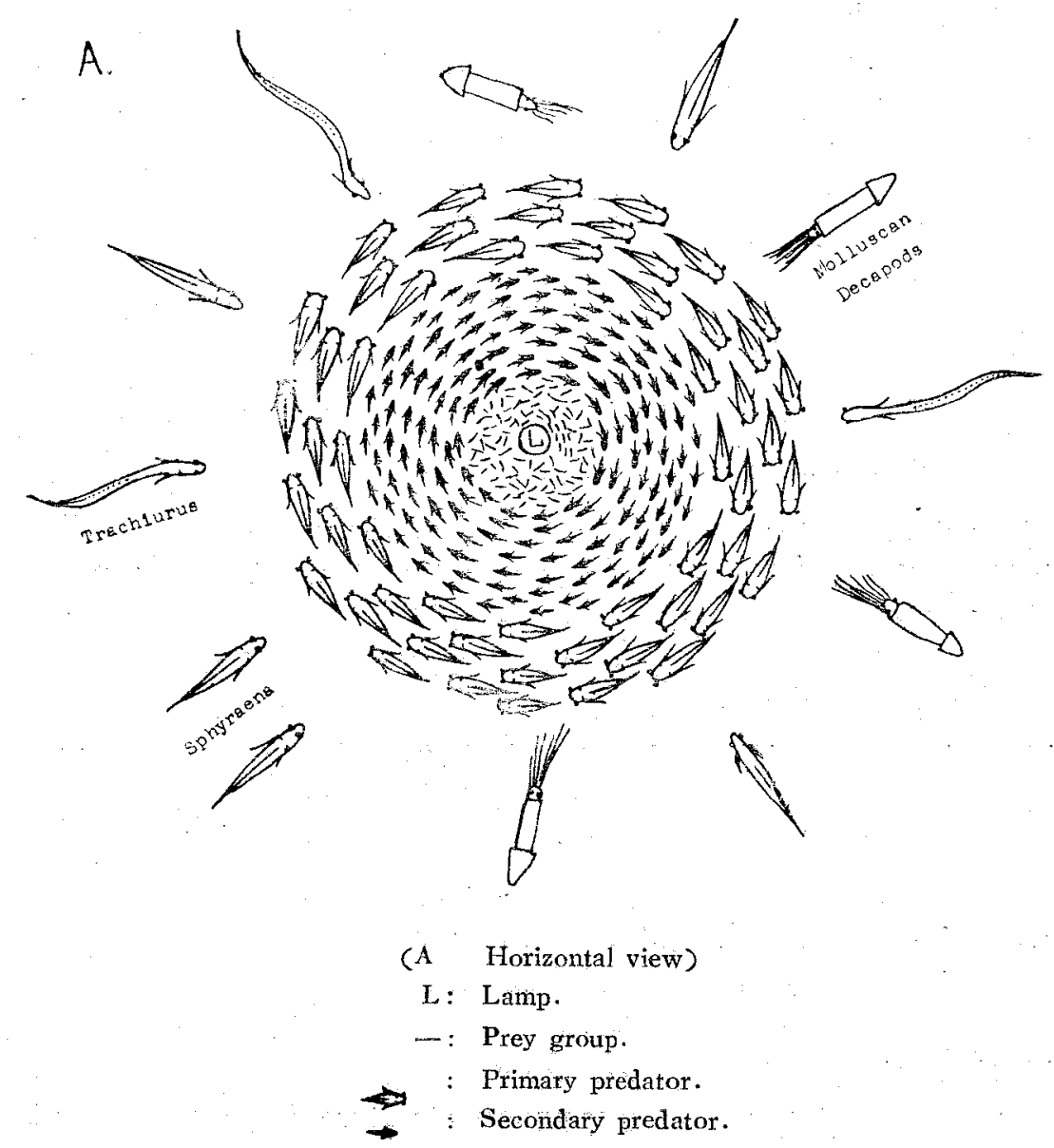

Other fishes show higher predators. 


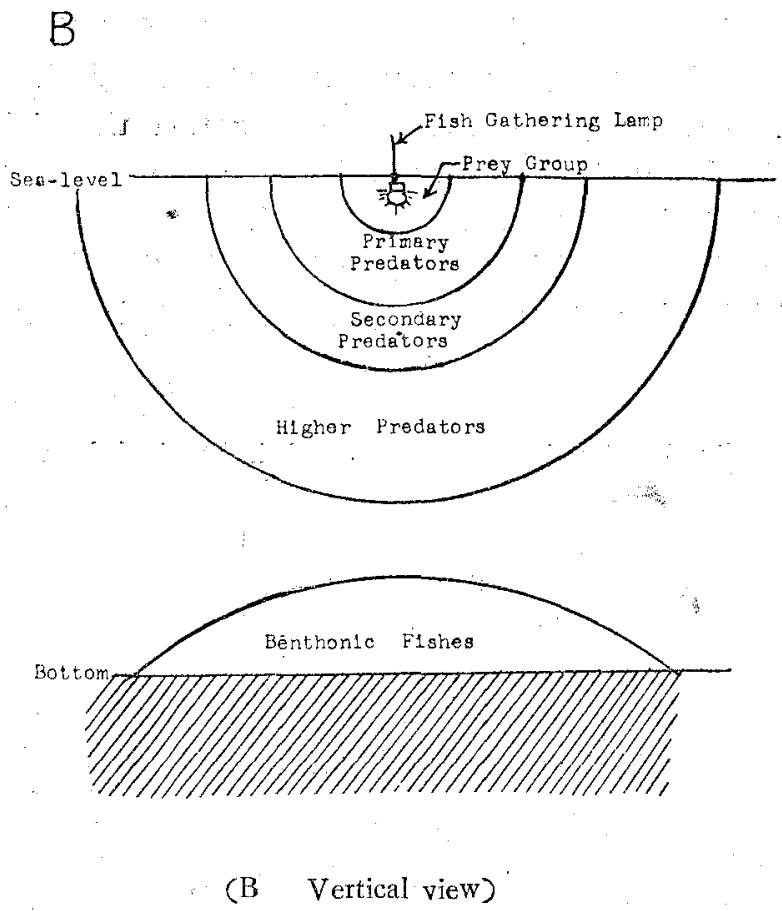

(2) Changes by the predating action.

When the predators increase in number or the predating action becomes remarkable in the periphery of the group in the standard form, the fishes of the lower food orders aggregate in more condensed mass in the center, but gradually abandon their central situations and the form of the group may be changed as is shown in Fig. 6 .

No. 2, No. 10 and No. 11) Aug. 23, 2h. 40 m.) or Fig. 6 represent the cases where the predating action is rather weak. Though the animals of the prey group are absent in the central part, they are not scattered, but are imigrating to the periphery. The arrangement of the other food order are quite the same as in the standard form; i.e., the inner in the situation the lower in the food order. No. 1 may be a transitory phase from the standard form to the "reverse form" to be explained below.

No. 3 and No. 11 (Aug. 22, 23h. 55m.) represent the cases in which the predating action is strong. The community structure becomes reversed completely from that of the standard form. The lower in the food order, the 
more peripheral in the situation. This structure may be called the "reverse form."

No. 31 and No. 33 show the cases in which the predating action is violent. When the predating action is strong but in a certain limit the group becomes unstable, but not scattered. If the predation becomes much stronger, the group under the lamp becomes very poor and consists of predators only of higher

Fig. 6. Eight actual cases modified by predating action.

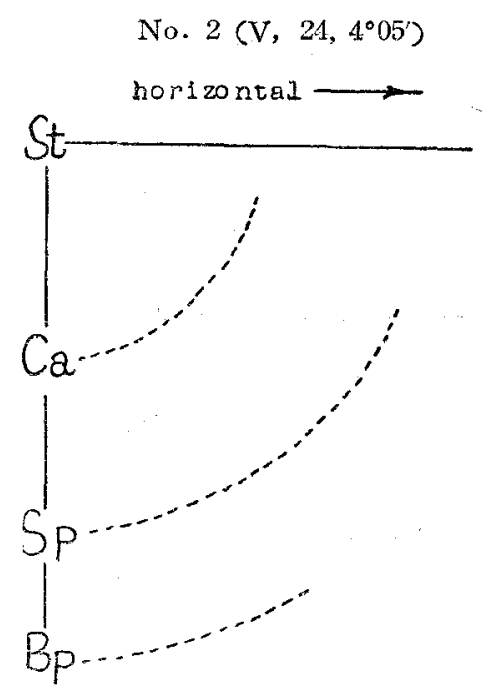

No. 3 (VIII, $\left.6,0^{c} 00^{\prime}\right)$

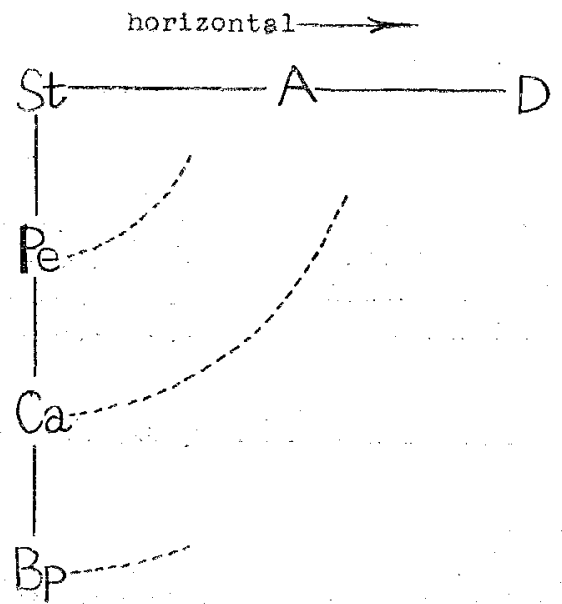

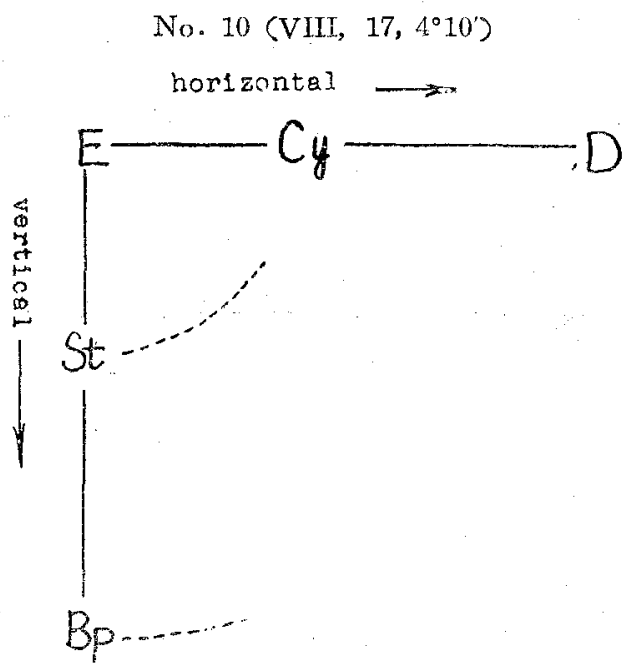

No, 11 (VIII, $22,23^{\circ} 55^{\prime}$ )

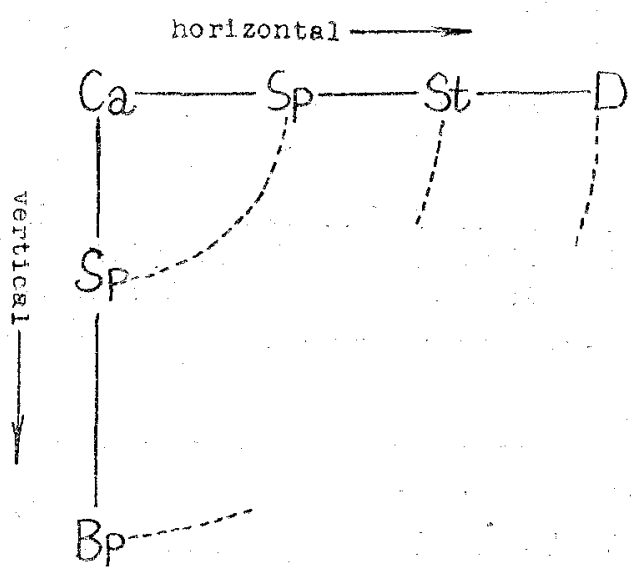



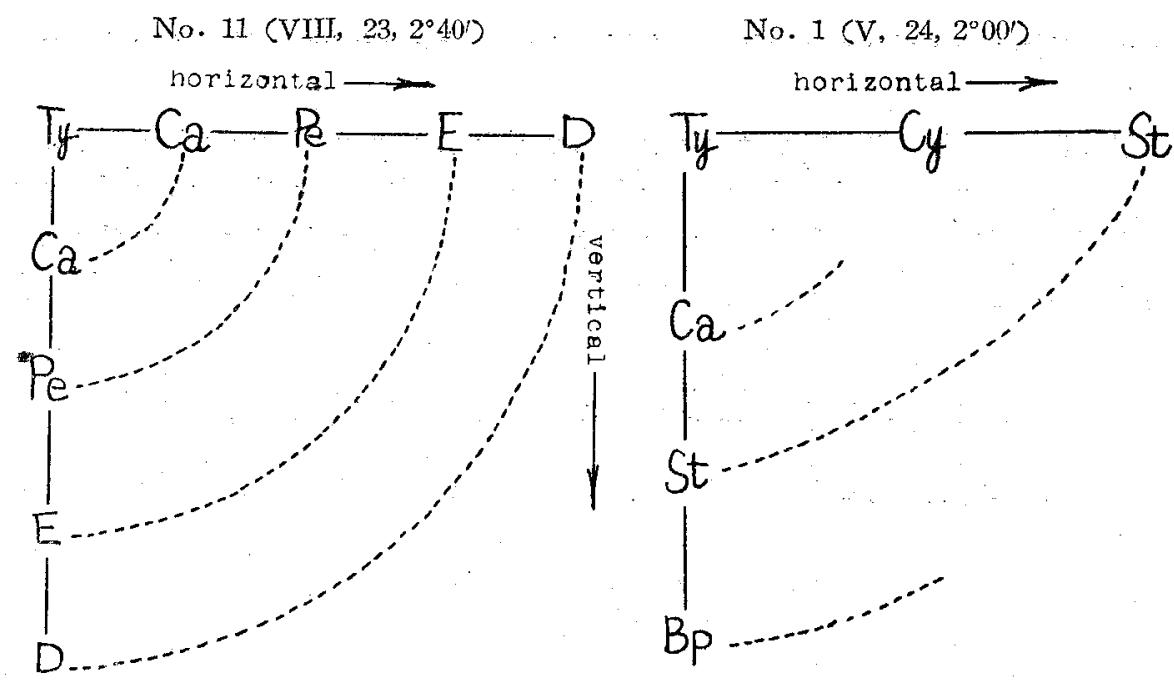

No. 31 (IX, 17, $\left.19^{\circ} 20^{\prime}\right)$

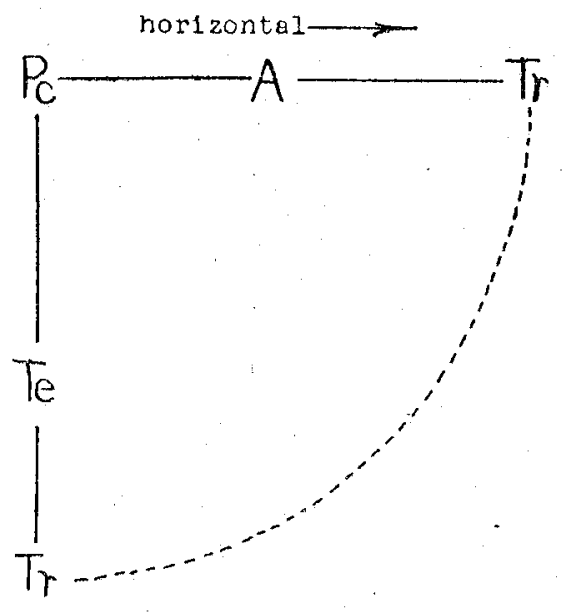

No. $33\left(\mathrm{IX}, 18,3^{\circ} 25^{\prime}\right)$

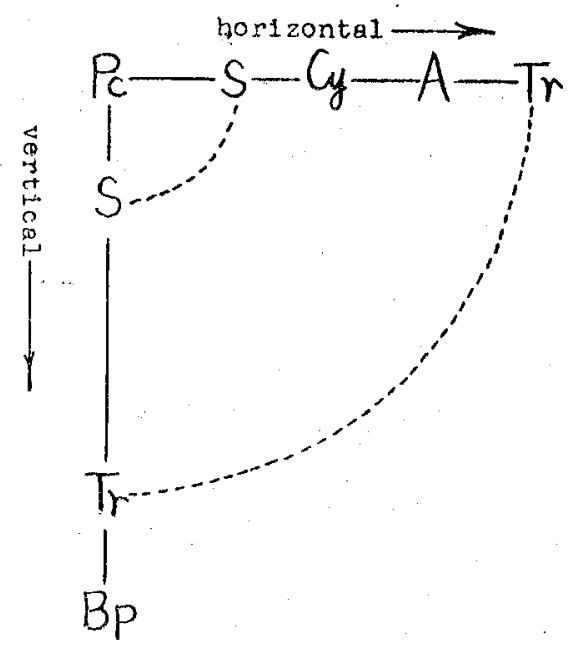

Pc: Plankıonic Crustaceans,

S: Shirasu stage of Lingraulis,

St: Stolephorus,

$\mathrm{E}$ : Engraulis,

Pe: Pempheris,

$\mathrm{Ca}$ : Carangidae,

Sp: Sphyraena,

D: molluscan Decapods,

$\operatorname{Tr}$ : Trichiurus,

A: Atherina,

$\mathrm{Cy}$ : Cypselurt:,

$\mathrm{Bp}$ : Benthonic Fishes,

Te: Tetraodontidae,

Ty: Tylosurus.

orders sometimes accompanied by fishes of much lower orders quite unrelated with predators.

(3) The modification caused by the current.

While the weak current has little influences, the strong current alters 
much the amount as well as the number of component species of the lamp community. The locomotive power of lamp animals is closely related with their size, which is a decisive factor to determine their food taking capacity. The animals of lower food orders are usually small in size and has poor locomotive power, and consequently they are unable to approach the lamp in strong currents. When the current flows very rapidly, any animals can not be seen under the lamp.

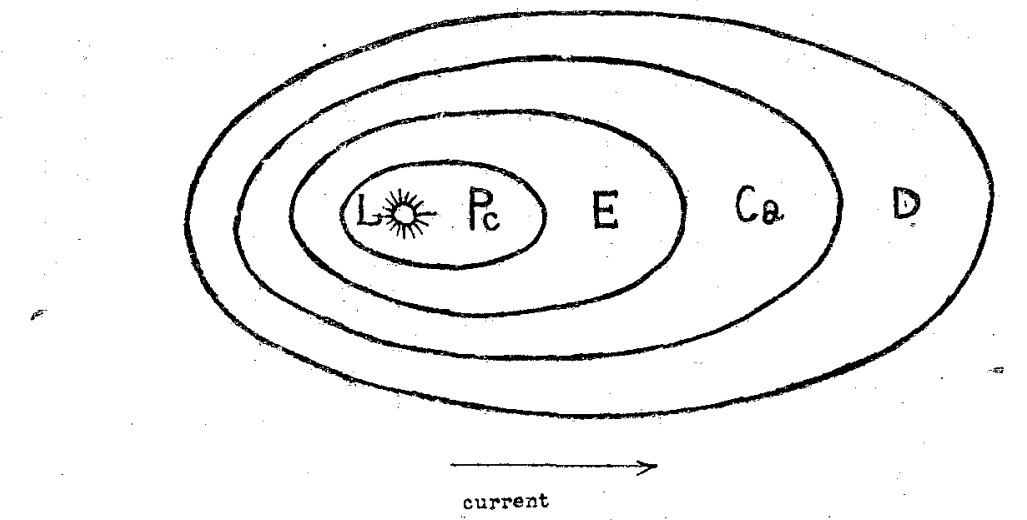

No. 8 (VIII, $12,4^{\circ} 00^{\prime}$ )

Fig. 7. Case No. 8, an example of modification by current.

L : Fish gathering lamp.

Pc: Plan'stonic crustaceans,

Ca: Carangidae.
E: Engraulis,

D: Molluscan decapods:

(4) Successional changes of the community structure under the same lamp.

i. The sequence of an mals assembling to the lamp.

The sequence of chief animals assembling to the lamp may be roughly conceivable from Table 4. Sphyraena is considered to be a very late arrival to light, because it was the third arrival in two cases and sixth in a case. Molluscan Decapods, which were the second or third arrivals, were all very small and were treated to belong to prey group. The assembling order of larger Decapods as the tertiary predator is much later. In a case when a sword-fish Trichiurus was the second arrival, no fish assembled after it. From these facts the order to assemble to the light in the above mentioned fishes may be as follows: Carangidae-Sphyraena-molluscan Decapods-Trichiurus. It is noteworthy that the order is quite parallel to the food order, except in the case of Stolephorus.

ii. Successional changes in the structure from the lighting to the dawn.

The changes are divided into two processes, the formation and the dispersion of the group, although the latter process can not be observed perfectly, 
Table 4. Order of arrival to the lamp:

\begin{tabular}{|c|c|c|c|c|c|c|c|c|c|c|c|}
\hline $\begin{array}{l}\text { Name } \\
\quad \text { of } \\
\text { Onimal } \\
\quad \text { of } \\
\text { arrival }\end{array}$ & 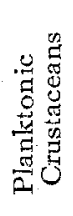 & 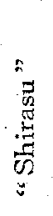 & 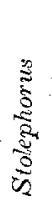 & 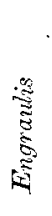 & $\frac{\sqrt{3}}{\sqrt[3]{*}}$ & 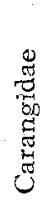 & 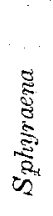 & 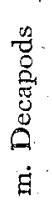 & 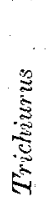 & : & 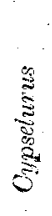 \\
\hline First & 28 & 6 & 2 & 3 & & & & & & 5 & 2 \\
\hline Second & 2 & 7 & 1 & 8 & 1. & 2 & & 3 & 1 & 7 & 4 \\
\hline Third & 1 & 1 & 3 & 6 & 3 & 2 & 2 & 2 & & 5 & 3 \\
\hline Forth & & 2 & 3 & 3 & 1 & 3 & & 1 & 3 & 2 & 2 \\
\hline Fifth & & & 1 & & & 1 & & 3 & & 2 & 1 \\
\hline Sixth & & & & & & 2 & 1 & 1 & & 1 & 1 \\
\hline Seventh - & & & 1 & & & & & 1 & & & \\
\hline Eighth & & & & & & & & 1 & & & \\
\hline
\end{tabular}

because it takes place in a very short time and moreover it becomes very hard to see through the water under the dawning sky.

After the lighting, such animals of the prey group as planktonic crustaceans, Polychaeta and Shirasu come first. They begin to appear under the lamp within a minute time, and increase gradually till they are surrounded by predator fishes, which disperse the former. Planktonic crustaceans are scattered around the lamp showing irregular whirling movements. The fishes of Shirasu stage appear at first in very small groups, each of which consists of only a few individuals, but these groups unite gradually one after the other to form one or two circulating shoals circulating around the lamp. Atherina and Cypselurus begin to visit the lamp before the above mentioned prey animals gather in abundance and keep themselves near the lamp, approaching or apart from the light. While Atherina has the tendency to increase in number and forms a group, such phenomenon could not be observed in Cypselurus.

By this time or a little before the time when the prey animals form stable shoals, the benthonic fishes begin to be angled and Engraulis of the deeper layer begin to float up and come to our sight. Engraulis swims, at the beginning, solitarily in random directions, but as it increases in number it forms several groups; the sphere in which these groups swim around becomes wider and wider with time, and at last, the groups are united into single group cir culating around the lamp. At this stage, the animals of the prey group show the decreasing tendency and Clupeids, Pempheris, Carangids and a few mollus- 
can Decapods begin to appear under the light. The directions of circulation of Engraulis groups are variable at first, but acquire the stableness with the time. The group grows gradually larger and denser but the diameter of the circulation becomes smaller and smaller.

Pempheris and Carangid fishes show similar behavior as Engraulis, increasing in number and forming a group in the same way, and begin to circulate outside the zone occupied by Engranlis. Fishermen set the net and induce the fish group into it by moving the light into the enclosure at the proper time when the circulatory movement of these fishes is settled in the stable condition. By the appearance of the predators, the shoal of Engraulis, however, becomes unstable again at that time.

Decapods appear in the periphery of the group a little after the formation of the stable group of Carangids and eat them. Lastly Trichiurus, Squalus, Coryphaena and Dolphinus approach the light and the shoals of Carangid fishes are destructed suddenly. Considering these processes, the time of setting the net must be decided most carefully. The destructing power of the predators of higher food orders on the lamp community is very strong, but wonderfully that of the net is rather weak. The fishes escaped from the net may assemble again to a nearby lamp. During these processes, benthonic fishes are angled at irregular intervals. Sarda, Scombrids and some benthonic fishes like Parapristipoma, which had been assembled in rather deeper layer, may float up to the upper layer, if the light is kept long enough.

About an hour before the dawn, the predating action of the benthonic fishes becomes suddenly stronger. „Stolephorus which remained till that time in the deeper layer under the light, floats up near the light and takes the place of Engraulis, which is pushed aside to the periphery and there eaten by Squids Spyraena and Trichiurus. Stolephorus is then attacked by Sphyraena and driven from the central part to the periphery. By this process, the reversal of the situation of Stolephorus and Sphyraena was observed at several times. In spite of the predating attack of Sphyraena, Stolephorus maintains the situation near the lamp and swims around it till the dawn, when the behavior of this fish become obscure, At the dawn Carangid fishes are the first to disappear from the group, then other fishes roughly in the order of food chain both in higher and lower directions. The benthonic fishes become gradually irresponsive to the bait after the dawn. 